\title{
Serum Zinc, Copper and Calcium Levels In Female Rheumatoid Arthritic Patients
}

\author{
Arifa Alam Jelly ${ }^{1}$, Shelina Begum², Sultana Ferdousi ${ }^{3}$
}

\begin{abstract}
Background: Rheumatoid Arthritis is a chronic multi-system autoimmune inflammatory disease, characterized by inflammatory synovitis involving symmetrical peripheral joints. Serum copper, zinc and calcium levels are altered in Rheumatoid Arthritis. Objective: To observe serum zinc, copper and calcium levels in patients with Rheumatoid Arthritis (RA). Methods: This cross sectional study was conducted in the Department of Physiology, Bangabandhu Sheikh Mujib Medical University (BSMMU), Shahbag, Dhaka from January to December 2010. For this, 60 female patients with Rheumatoid arthritis aged 30-50 years were included in the study group. The patients were selected from outpatient Department of Rheumatology wing of medicine in Bangabandhu Sheik Mujib Medical University (BSMMU). For comparison age and BMI matched 30 apparently healthy female were also studied. Serum calcium level was measured by Colorimetric method. Serum zinc and copper was measured by Spectrophotometric method. For statistical analysis, independent sample t test was performed by using SPSS for windows version-12. Results: In this study, serum zinc and calcium levels were significantly lower $(\mathrm{p}<0.001)$ and serum copper level was significantly higher $(\mathrm{p}<0.001)$ in the RA patients than those of control. Conclusion: This study may conclude that hypozincemia and hypocalcemia and hypercupremia occur in RA. Therefore early detection of these micronutrient abnormalities may be helpful for the physicians to prevent various complications in RA patients.
\end{abstract}

Key words: Zinc, Copper, Calcium, Rheumatoid arthritis.

J Bangladesh Soc Physiol. 2012 June; 7(1): 18-22 For Authors Affiliation, see end of text.

http://www.banglajol.info/index.php/JBSP

\section{Introduction}

$\mathbf{R}$

heumatoid arthritis (RA) is a common inflammatory connective tissue disease with worldwide prevalence of $1 \%$, but the rate varies among different groups of people. Women are affected 2 to 3 times more often. Onset may be at any age; most often between $3^{\text {rd }}$ to $5^{\text {th }}$ decades. Onset can occur during childhood or in the elderly. 1,2

The etiology of rheumatoid arthritis remains unclear, but there is evidence of genetic

Received February 2012; $\quad$ Accepted May 2012

18 predisposition to the disease. The presence of HLA-DR4 is significantly commoner among sufferers of rheumatoid arthritis who are white. ${ }^{1}$ It is a chronic inflammatory disease of the joints in which pain, swelling and limited mobility of the joint are the most prominent features. ${ }^{3}$ Rheumatoid factor is a common marker for rheumatoid arthritis which is present in about $70 \%$ of patient. ${ }^{4}$ It was reported that inflammation in rheumatoid arthritis patient causes decrease serum level of zinc resulting from zinc sequestration in the liver, pancreas and intestine due to cytokine induced metalloenzyme

J Bangladesh Soc Physiol. 2012, June; 7(1): 18-22 
synthesis. Moreover it was found that decrease serum zinc level results in T lymphocyte function disorder which is involved in the pathogenesis of rheumatoid arthritis. ${ }^{5}$

Literature review show increased level of ceruloplasmin as a part of acute phase reaction cause altered metabolism of copper and zinc. ${ }^{6-}$ ${ }^{7}$ Some investigators observed increased serum copper level in adults and juvanile rheumatoid arthritis and it appeared to be associated with immune mediated inflammatory process of rheumatoid arthritis. ${ }^{8-9}$

It was also suggested that increased copper and zinc deficiency might be involved in the development and progression of rheumatoid arthritis. ${ }^{10-11}$

As cofactor of several enzymes associated with collagen and bone metabolism and immune function, role of copper and zinc is important in chronic inflammatory disease. ${ }^{12}$

Copper and zinc physiology is considered a matter of great interest because of the possibility of being able to activate many key enzymes in the cellular metabolism. Copper and zinc are essential nutrients, and their daily intake is necessary to prevent diseases. ${ }^{13}$

Several researchers observed that serum calcium levels are lower in patients with rheumatoid arthritis than in healthy people. ${ }^{14-15}$ Mean total body calcium was reduced in patients with rheumatoid arthritis and strongly suggested that the reduction in bone mass is an integral feature of the disease. ${ }^{15}$

Large numbers of subjects in Bangladesh are affected by rheumatoid arthritis (RA). Females are more affected than male. Women of low socioeconomic status have an increased risk of zinc deficiency. With this background this study was undertaken to observe the serum zinc, copper and calcium levels in Bangladeshi rheumatoid arthritis women to find out the possible role of these micronutrients in rheumatoid arthritis.

\section{Methods}

This cross sectional study was carried out in the Department of Physiology, Bangabandhu Sheikh
Mujib Medical University, Dhaka between January to December 2010. For this, 60 diagnosed case of female rheumatoid arthritis patients aged 20-50 years were recruited in the study group (group B). For comparison age and BMI matched 30 healthy women were also studied (group A). Following simple random technique, the patients were selected from the out patient Department of the Rheumatology wing of the department of Medicine in Bangabandhu Sheikh Mujib Medical University (BSMMU) Dhaka and control was selected from the attendants of the patients. Subjects with history of any heart disease, hypertension, diabetes mellitus, chronic renal failure, hypothyroidism or hyperthyroidism, pregnancy, oral contraceptive, insertion of copper $\mathrm{T}$ were excluded from the study. After selection, the aim and benefit of the study was explained to each subject. When they agreed for participation, a written informed consent was taken. Detailed family history, medical history was taken and a thorough physical examination of them were done and all information were recorded in a data schedule. With all aseptic precaution, $5 \mathrm{ml}$ of venous blood was collected from ante-cubital vein two hours after breakfast from all subjects for estimation of micronutrients. Serum calcium was measured by colorimetric method and serum zinc and copper was measured by Spectrophotometric method in the laboratory of the department of Physiology of BSMMU, Dhaka. Data was expressed as Mean \pm SD. For statistical analysis, independent sample $t$ test was performed by using SPSS windows version-12.

\section{Results}

In this study, both the groups were matched for age and BMI (Table I).

Mean serum zinc and calcium levels were significantly lower and serum copper level was significantly higher in group $B(p<0.000)$ in comparison to those of group A. (Table II). Again, in this study 38.34\% RA patients had hypozincemia, $58.34 \%$ patients had hypocalcaemia and $43.34 \%$ had hypercupremia. (Figure 1). 
Table I : Age and BMI in two groups $(\mathrm{n}=90)$.

\begin{tabular}{lccc}
\hline Parameters & Group A $(\mathrm{n}=30)$ & Group B $(\mathrm{n}=60)$ & P value \\
\hline Age $($ years $)$ & $36.9 \pm 9.97$ & $37.07 \pm 9.77$ & $0.939784^{\mathrm{ns}}$ \\
BMI $\left(\mathrm{Kg} / \mathrm{m}^{2}\right)$ & $23.18 \pm 3.69$ & $24.06 \pm 3.83$ & $0.297011^{\mathrm{ns}}$ \\
\hline
\end{tabular}

Data expressed by Mean \pm SD Group A = Control, Group B = Rheumatoid arthritis patient, BMI=Body mass index, $\mathrm{ns}=$ Non significant $\mathrm{p}>0.05, \mathrm{n}=$ Number of subjects

Table II: Mean \pm SD Serum Zinc, Copper And Calcium Levels In Two Groups ( $\mathrm{n}=90)$.

\begin{tabular}{lccc}
\hline Parameters & Group $\mathrm{An}=30$ & Group B n=60 & P value \\
\hline Serum zinc $(\mu \mathrm{gm} / \mathrm{dl})$ & $109 \pm 14.65$ & $89.58 \pm 12.29$ & $0.000^{* * *}$ \\
Serum copper $(\mu \mathrm{gm} / \mathrm{dl})$ & $114 \pm 12.58$ & $142.75 \pm 20.37$ & $0.000^{* * *}$ \\
Serum calcium $(\mathrm{mg} / \mathrm{dl})$ & $9.36 \pm 0.77$ & $8.54 \pm 0.78$ & $0.000^{* * *}$ \\
\hline
\end{tabular}

Group $\mathrm{A}=$ Control, Group B $=$ Rheumatoid arthritis patient, $* * *=\mathrm{p}<0.000$

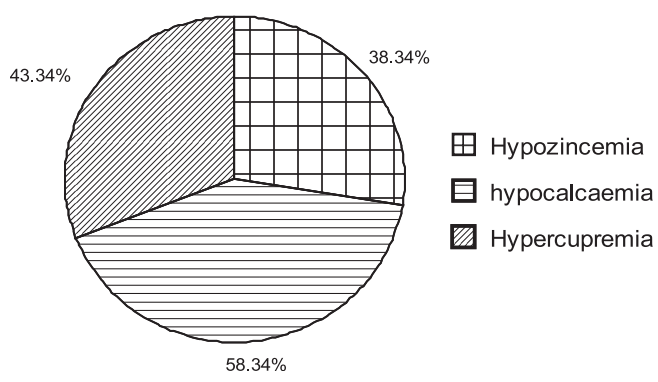

Figure 1: Distribution of the subjects by serum Zinc, copper and calcium in Rheumatoid arthritis patients $(\mathrm{n}=60)$

\section{Discussion}

The results of this study showed significantly lower serum zinc and calcium levels and significantly higher copper level in female rheumatoid arthritis patient than control. Similar observations were reported by other investigators of different countries. ${ }^{5,8-12,14-15}$ Such alteration in these mineral concentrations in blood of RA is crucial to their health as these are integral part of oxidative enzyme activity.

It has been reported that increased numbers of female patients suffer from autoimmune diseases because specific female hormones may be the predisposing factors of this disease. ${ }^{16}$
This is supported by the fact that formation of reactive oxygen species and lipid peroxides may play an important role in rheumatoid arthritis. Moreover, it was observed that reduced concentrations of antioxidants in the blood increase the probability of the occurrence of rheumatoid arthritis. ${ }^{17}$

In RA, as a part of chronic inflammatory response Interleukin-1 rapidly synthesizes C- reactive protein by hepatocytes which are attributed to hypozincemia in rheumatoid arthritis patient. ${ }^{18}$ It has also been suggested that accumulation of zinc in the liver and in the injured tissue, such as synovial fluid of arthritic patients lead to hypozincemia develop in RA. ${ }^{19}$

The increased copper level in RA was found to be associated with inflammatory response resulting from oxidative stress. ${ }^{20}$ It was suggested that the cytokines enhanced the release of copper thioneins during the oxidative brust of polymorphonuclear cells that led to hypercupremia in rheumatoid arthritis patients. ${ }^{21}$ It is reported that elevated serum copper levels depends upon increased synthesis of ceruloplasmin by the liver which is an antioxidant, copper containing protein whose role in arthritis is to neutralize free oxygen radicals. ${ }^{22}$

J Bangladesh Soc Physiol. 2012, June; 7(1): 18-22 
The link between hypozincemia and hypercupremia has been explained by the fact that zinc deficiency seems to increase serum copper by inducing intestinal metallothionein and liver ceruloplasmin and enhance absorption of copper from food. 23

In addition to zinc and copper, calcium levels are also affected in RA patients. Research evidence showed that calcium and phosphate metabolism is altered in RA.

Increased load of free radical associated with inflammatory disease may be related to the body calcium/phosphorus ratio. ${ }^{24}$ In RA patient there is alteration in oxidative metabolism which lead to disruption in intracellular ionic environment and altered calcium levels. ${ }^{24}$ Some authors suggested that decreased mean total body calcium levels in rheumatoid arthritis patients are an integral feature of rheumatoid arthritis. 15 Whereas other suggested hypocalcaemia results from drugs used in RA treatment. ${ }^{15}$

In the present study, hypozincemia may be related to consumption of zinc in inflammatory tissue and liver and hypercupremia is most likely related to the cytokine related inflammatory response. In addition, hypocalcaemia may be due to the disease activity.

\section{Conclusion}

So, it may be concluded that these micronutrients abnormality is a common feature in RA patients. Therefore, routine estimation of serum zinc, copper and calcium may be suggested by the physicians to prevent the harmful effects of the abnormal concentration of the micronutrient in RA patients.

\section{Authors Affiliation}

*1. Arifa Alam jelly, Assistant professor, Department of Physiology with Biochemistry, Pioneer Dental College,Dhaka. Email:aa_jelly@yahoo.com

2. Shelina Begum, Professor and Chairman, Department of physiology, Bangabandhu Sheikh Mujib Medical University (BSMMU), Shahbag, Dhaka. Email: shelina1985@gmail.com

3. Sultana Ferdousi, Associate Professor, Department of physiology,Bangabandhu Sheikh Mujib Medical University (BSMMU), Shahbag, Dhaka. Email: sferdousiratna@gmail.com

*for correspondence

J Bangladesh Soc Physiol. 2012, June; 7(1): 18-22

\section{References}

1. Akil M, Amos RS. ABC of Rheumatology: Rheumatoid arthritis-I: Clinical features and diagnosis. BMJ. 1995; 310:587-590.

2. Altman RD. Rheumatoid Arthritis (RA): Joint Disorders: Merck Mannual books of Patient symptoms. Porter RS,Kaplan JL, Homeier BP (eds). [Internet]. [Update $2008 \mathrm{Feb}$; cited 2009 Jun 24]. Available from: http://www.merckbooks. com/symptoms/index.htm.

3. Voskuyl AE. The Heart and cardiovascular manifestations in Rheumatoid Arthritis. Rheumatology [Internet] [cited 2010May] 2006; 15(4):iv4- iv7.

4. Arnett FC, Edworthy SM, Bloch DA, McShane DJ, Fries JF, Cooper NS, Healey LA, Kaplan SR, Liang MH, Luthra HS. The American rheumatism association 1987 revised criteria for the classification of Rheumatoid Arthritis. Arthritis Rheum.1988; 31(3):315-24.

5. Caglayan O, Aydog Y.S. Serum zinc and Copper Levels In Rheumatoid Arthritis. Journals of Islamic Academy of Sciences.1997; 10(1):19-24.

6. Erskine RJ, Bertlett PC. Serum Concentrations Of Copper, Iron And Zinc During Escherichia ColiInduced Mastitis. J Dair Sci. 1903; 76:408-413.

7. Vukicevic S, Ana M, Kos K. The role of tumor necrosis factor in the generation of acute phase response and bone loss in rats with talc granulomatosis. Lab invest. 1994; 70:386-391.

8. Milanino R, Frigo A, Bambara LM, Marrella M, Moretti U, Biasi D, Gasperini R, Mainenti L, Velo GP. Copper and zinc status in rheumatoid arthritis: studies of plasma, erythrocytes and urine and their relationship with disease activity markers and pharmacological treatment. Clin Exp Rheumatol. 1993; 11(3):271-81.

9. Honkanen VE, Pelkonen P, Mussalo-Rauhamaa H, Lehto J, Westermarck TW. Serum trace elements in juvenile chronic arthritis. Clin Rheumatol. 1989; 2:64-70

10. Rainsford KD. Environmental ion perturbations, especially as they affect copper status, are a factor in the etiology of arthritic conditions: a hypothesis. In: Sorenson JRJ, editor. Inflammatory disease and copper. Clifton, NJ; Huamana Press; 1982.13743.

11. Simkin PA. Oral zinc sulphate in rheumatoid arthritis. The Lancet. 1976; 308:539-542. 
12. Altomonte L, Caricchio R, Galossi A, Mirone L, Ruffini MP, Magaro M. Serum Zinc And Copper In Active Rheumatoid Arthritis: Correlation With Interleukin 1â And Tumour Necrosis Factor. Clin Rheumatol. 1998; 17:378-382.

13 WHO. Trace Elements in Human Nutrition and Health. Report of a WHO Consultation. Geneva: WHO 1996.

14. Scott DL, Farr M, Hawkins CF, Wilkison R, Bold AM. Serum calcium levels in rheumatoid arthritis. Ann of the Rheum Dis 1981; 40:580-583.

15. Reid DM, Kennedy NSJ, Smith MA, Tothill P, Nuki G. Total body calcium in rheumatoid arthritis: effects of disease activity and corticosteroid treatment. BMJ 1982; 285(31):330-332.

16. Kelly's Textbook of Rheumatology. $6^{\text {th }}$ ed. USA: Sanders Company; 2001. p321-324.

17. Sklodoska M, Gromadzinska J, Biernacka M, Wasowicz W, Wolkanin P, Marszalek A, Brozik H, Pokuszynska K. Vitamin E, Thiobarbituric acid reactive substance concentrations and super oxide dismutase activity in the blood of children with juvenile rheumatoid arthritis. Clin exp Rheum. $1996 ; 14: 433-439$.
18. Gambino R. C-reactive protein undervalued, underutilized. Clin Chem. 1997; 43:2017-8.

19. Powanda MC, Cockerell GL, Pekarek RS. Amino acid and zinc movement in relation to protein synthesis early in inflammation. Am J Physiol. 1973; 225:399-401.

20. Taneja SK, Mandol R. Assessment of mineral status (zn, cu, mg and $\mathrm{mn}$ ) in rheumatoid arthritis patients in Chandigarh, India. rr. 2009; 1(e5):16-20.

21. Driessen C, Hirv K, Kinchner H, Rink L. Zinc regulates cytokine induction by super antigens and lipopolysaccharide. Immunology. 1995; 84:2727.

22. Zoli A, Altomonte L, Caricchio R, Galossi A, Mirone L, Ruffini MP, Magaro M. Serum zinc and copper in active Rheumatoid Arthritis: Correlation with interleukin 1â and tumour necrosis factor. Clin Rheumatol. 1998; 17:378-382.

23. Brewer GJ, Hill GM, Dick RD, Prasad AS, Cossack ZT. Interactions of trace elements: clinical significance. J Am Coll Nutr. 1985; 4:33-4.

24. Walwadker SD, Suryakar AN, Katkam RV, Kumbar KM, Ankush RD. Oxidative stress and calciumphosphorus levels in Rheumatoid Arthritis. Ind J Clin Biochem. 2006; 21(2):134-137. 